\title{
Seasonal variation and time trends in childhood asthma in England and Wales 1975-81
}

\author{
A KHOT, R BURN, N EVANS, C LENNEY, W LENNEY
}

\begin{abstract}
In England and Wales hospital admissions for childhood asthma almost trebled over the period 1975-81. This may have reflected a true increase in the incidence of acute asthma, a swing from primary to hospital care, or both. The trend was not due to a change in diagnostic fashion. Monthly admissions showed a pronounced seasonal variation with fewest admissions in winter, rising in spring and early summer to peak in the autumn. A deep admission trough was present in August. The monthly admission profile was very similar throughout England and Wales, suggesting that major "trigger" factors were responsible.
\end{abstract}

\section{Introduction}

Seasonal variation in asthma has been recognised since $400 \mathrm{BC}$, when Hippocrates noted that it was more common and apt to be worse in the autumn. ${ }^{1}$ Studies in Australia, ${ }^{2}$ the United States, ${ }^{3-5}$ and Europe ${ }^{8}$ have documented a similar trend but there is little published work from Britain. In a recent study ${ }^{7}$ we reported the presence of an autumn peak in admissions for childhood asthma in Brighton and the South East Thames region, as well as noting a steadily increasing admission rate in Brighton from 1971 to 1980 . The increasing admission rate was in keeping with that in other studies. ${ }^{8}$ The Tim of this study was to document and validate statistically the seasonal variation and recent time trends in admissions for childhood asthma in England and Wales.

\section{Method}

SOURCE OF DATA

Monthly hospital discharge data were sought from the Hospital Activity Analysis listings for each health region in England and Wales for the period 1975-81. Listings were obtained by age (0-4 and 5-14 years) for the following disease categories as principal diagnosis: asthma (International Classification of Diseases (ICD) 493); acute bronchitis, which includes acute bronchiolitis (ICD 466); and bronchitis unqualified (ICD 490). Complete data were obtained for Wales and 12 of the 14 regions in England. Listings were unavailable from two of the English regions for technical reasons. Mid-year national and regional estimates of population were obtained from the Office of Population Censuses and Surveys.

Royal Alexandra Hospital for Sick Children, Brighton BN1 3JN A KHOT, $\mathrm{MB}, \mathrm{DCH}$, research associate N EVANS, MRCP, DCH, consultant paediatrician C LENNEY, SRN, research nurse

W LENNEY, MD, MRCP, consultant paediatrician

Brighton Polytechnic, Moulscoomb, Brighton R BURN, MSC, FSS, statistician

Correspondence to: Dr A Khot.

\section{STATISTICAL METHOD}

For each age group the monthly admissions from each region were added together and estimates of the numbers of admissions per million for England and Wales (after adjusting for the two missing regions) obtained using mid-year estimates of population. This procedure was followed separately for the three disease codings.

The object of the analysis was to identify and describe the seasonal pattern in the three series. The statistical method used was to isolate the seasonal component by first removing the underlying trend, as described by Kendall. ${ }^{10}$ The importance of accounting for the trend in estimating seasonality is well recognised in statistical publications. ${ }^{11}$ The trend was estimated by means of a centred 12 point moving average and the trend values divided into the series. The resulting values were averaged for each month over the whole time period of the series and expressed as percentages. These 12 percentages were taken as representing the seasonal profile of each series.

\section{Results}

\section{TIME TRENDS}

Figure 1 shows the monthly asthma admission rate and trend for both age groups during the study period. A steadily increasing trend was observed. Figure 2 shows the admission trends in both age groups for the three disease codings asthma (ICD 493), acute bronchitis (ICD 466), and bronchitis unqualified (ICD 490). The number of admissions coded as bronchitis unqualified changed little in either age group over the period. Admissions for acute bronchitis (including acute bronchiolitis) increased slightly in the younger age group. In the 5-14 year age group the numbers of admissions for acute bronchitis or bronchitis unqualified were very low.

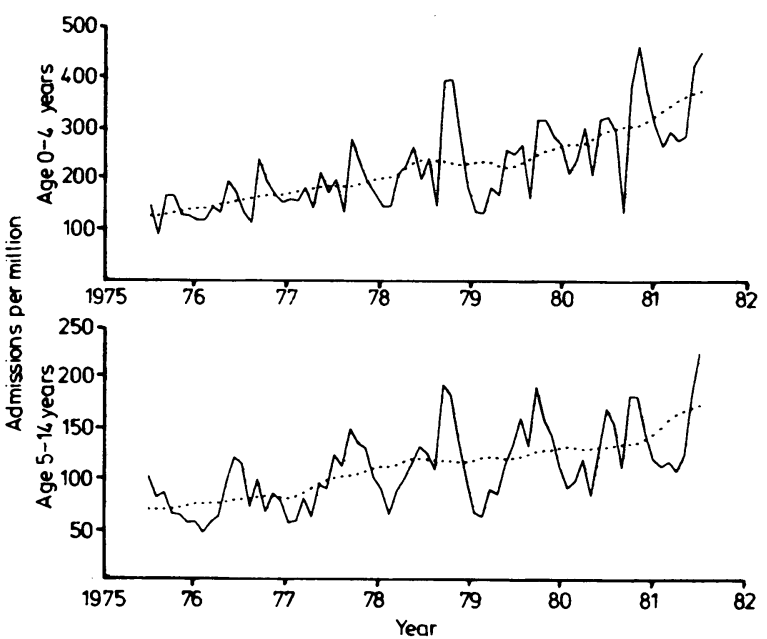

FIG 1-Monthly hospital admissions for asthma (ICD 493), with superimposed trend, in England and Wales during 1975-81 (source Hospital Activity Analysis).

SEASONAL VARIATION

A recurring seasonal pattern of admissions for asthma was evident in both age groups (fig 1). Figure 3 shows the monthly variation in admissions during the study period expressed as a percentage of the trend. The two age groups had a similar pattern of admissions. Admission rates were lowest in January and February (roughly $30 \%$ 
below the trend) and increased in March to peak in September (when they were roughly $40 \%$ above the trend). A small trough was observed in April and a deeper one in August ; the latter was more pronounced in the younger age group.

Figure 4 shows the monthly variations in acute bronchitis and bronchitis unqualified expressed as a percentage of the trend. Admissions for acute bronchitis were more common in February and March with a trough in August. The profile for bronchitis unqualified was less clear, but in both age groups there was an increase in winter and autumn with a deep trough in August.

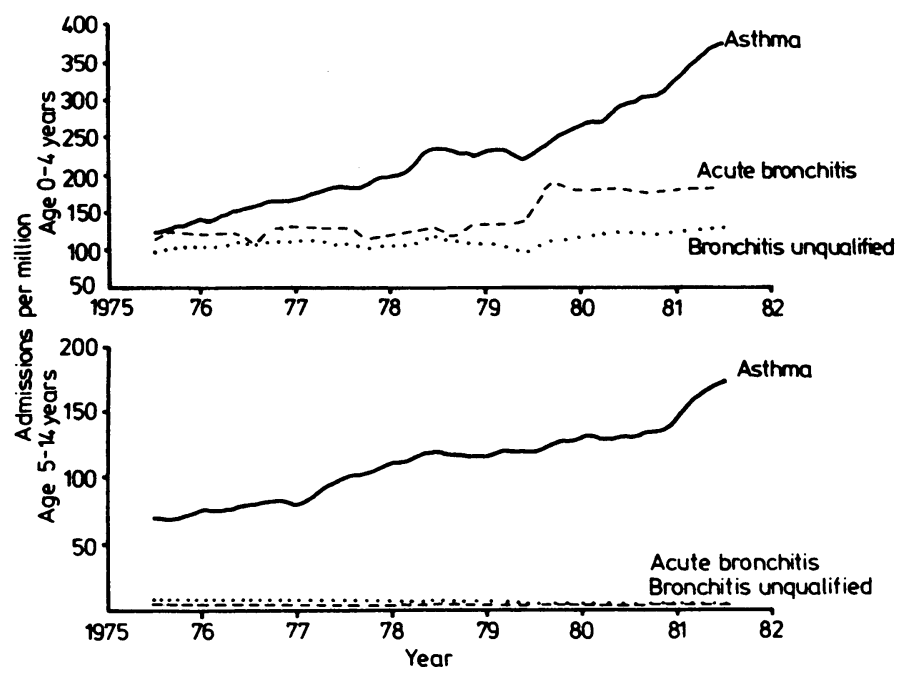

FIG 2-Trends in admissions for asthma (ICD 493), acute bronchitis (ICD 466), and bronchitis unqualified (ICD 490) in England and Wales during 1975-81 (source: Hospital Activity Analysis).

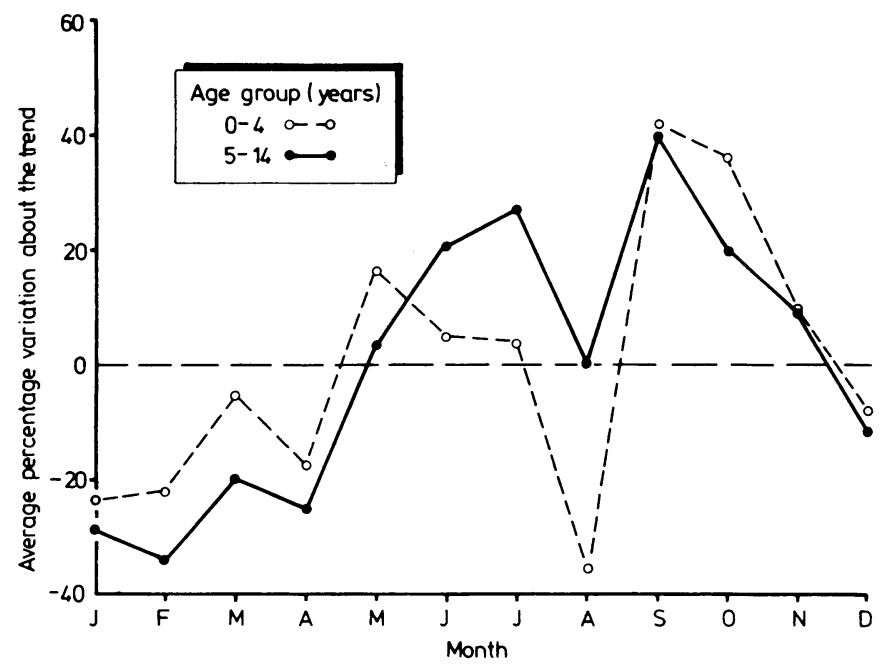

FIG 3-Average monthly variation in admissions for childhood asthma (ICD 493 ) in England and Wales during 1975-81.

\section{Discussion}

These results show clearly that in England and Wales admissions for childhood asthma are much more common in autumn. This agrees with studies from other countries ${ }^{2-6}$ together with a recent letter from the Office of Population Censuses and Surveys. ${ }^{12}$ The steady increase in hospital admissions from 1975 to 1981 indicates that the trend noted by Anderson $^{8} 9$ is continuing. This trend may have been influenced by several factors.

Firstly, Hospital Activity Analysis cover may have increased between 1975 and 1981. Hospital In-Patient Enquiry returns, however, indicate that in 1975 the Hospital Activity Analysis system already covered $95 \%$ of admissions, and by 1980 this had risen to $98 \%$. This small increase is unlikely to have influenced the trend in childhood asthma.

Secondly, most asthma synonyms, including wheezy bronchitis, recurrent wheezing, and bronchitis asthmatiformis, would have been coded as bronchitis unqualified (ICD 490). We found no evidence that a reduction in the use of this coding accounted for the large increase in admissions coded as asthma (ICD 493). Similarly, acute bronchitis (ICD 466), which includes acute bronchiolitis, did not decrease over the study period. These results suggest that a change in diagnostic fashion was not contributory.

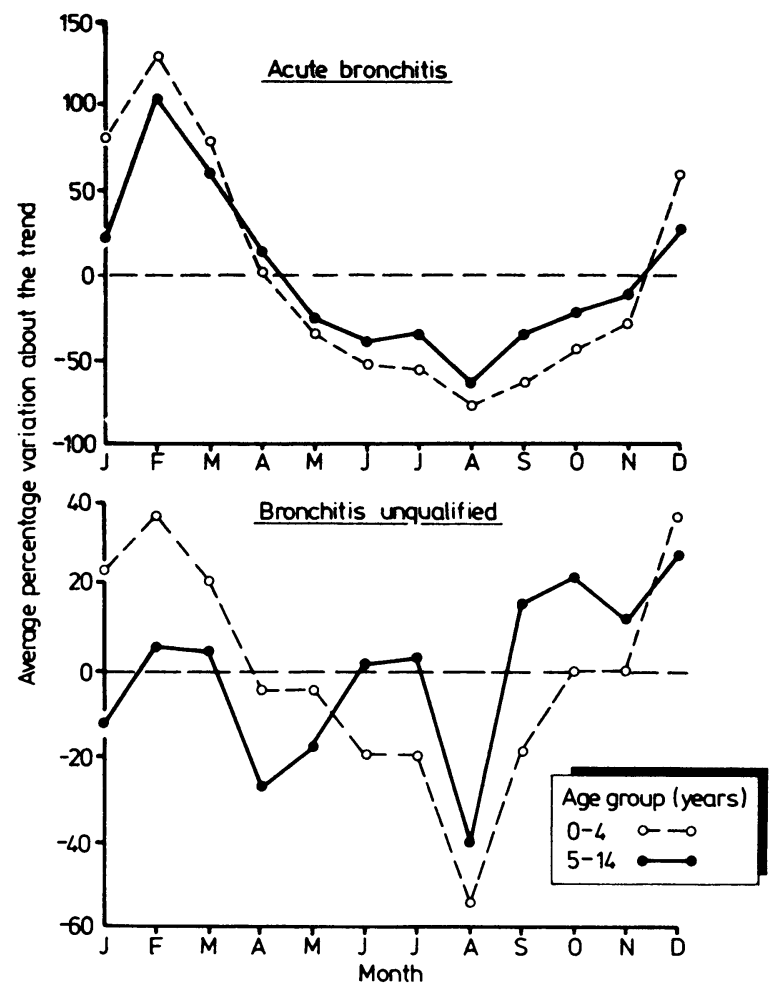

FIG 4-Average monthly variation in children's admissions for acute bronchitis (ICD 466) and bronchitis unqualified (ICD 490) in England and Wales during 1975-81.

Thirdly, the trend may have reflected an alteration in admission criteria and an increasing hospital role in the care of asthmatic children. The "open door" attitude of many departments and improvements in medical care may have influenced the trend, with a tendency to earlier referral, self referral, and readmission. ${ }^{\circ}$ This may have been encouraged by the availability and efficacy of nebulised bronchodilator treatment, though admissions were rising ${ }^{8}$ before this treatment was advocated. ${ }^{13} 14$ Availability of beds is not a limiting factor in paediatric admissions.

Lastly, we cannot exclude the possibility that there was a true increase in the incidence of acute childhood asthma.

We were surprised by the similarity of the monthly asthma admission profiles in our local and the national data. The winter months consistently had the smallest number of admissions, rising in spring and early summer to peak in the autumn. Each region had a similar admission profile and, assuming that the admission rate is a reflection of the prevalence of acute asthma, probably the trigger factors responsible for initiating attacks are closely similar throughout England and Wales.

Information from several regions suggests that the seasonal variation of acute bronchitis in the under $5 \mathrm{~s}$ reflects the incidence of acute bronchiolitis. The seasonal variation of bronchitis unqualified suggests that it contained some asthmatics.

The rise in admissions for asthma in spring and early summer 
may have been related to increasing tree and grass pollen counts. Many factors may have contributed to the larger September peak. Parents often remark that their children start to wheeze when the weather changes. The onset of cold weather in the autumn has been shown to be related to symptoms of asthma. ${ }^{61516}$ The acquisition of viral infections, ${ }^{17}$ the seasonal prevalence of fungal spores, ${ }^{18}{ }^{19}$ and the variation in the house dust mite population ${ }^{20}{ }^{21}$ may contribute.

The two troughs in admissions in April and August were unexpected findings, and the contribution of artefact cannot be totally excluded. The troughs occurred during "holiday" months, but children who require admission while on holiday in England and Wales will still be recorded in the Hospital Activity Analysis listings. Only a small proportion of the population take holidays abroad. There may be reticence to seek medical advice while on holiday, but a genuine decrease in the incidence of acute asthma cannot be excluded. This may reflect decreased stress during the school holidays, though the phenomenon was present and more pronounced in the preschool age group. Paradoxically deaths from asthma in the 5-14 year age group peak in August. ${ }^{22}$

The steady increase in hospital admissions for childhood asthma in England and Wales needs further investigation to assess whether it reflects an increase in acute asthma or a swing from primary to hospital care. The clear seasonal variation is consistent throughout England and Wales, suggesting that similar environmental trigger factors are responsible for provoking attacks. Detailed studies of these factors are needed to clarify which are relevant. Assuming that the seasonal variation reflects the incidence of acute asthma, this should be considered when planning therapeutic trials.

We thank the regional statistical and Hospital Activity Analysis officers for their cooperation in obtaining the listings. We also thank Dr H R Anderson, of the department of clinical epidemiology and social medicine at St George's Hospital, London, for advice and encouragement.
AK is supported by a grant from the Royal Alexandra Children's Hospital Centenary Fund, Brighton, and CL is supported by a grant from the South East Thames Regional Health Authority through the LORS Fund. We are very grateful to both these funds.

\section{References}

' Hippocrates. Aphorisms III. 19.22.

${ }^{2}$ Derrick EH. Asthma and the Brisbane climate. Aust NZ F Med 1972;3:235-46. Booth S, De Groot IDO, Markush R, Horton RSM. Detection of asthma epidemics in seven cities. Arch Environ Health 1965;10:152.

Salvaggio J, Hasselblad V, Seabury J, Heiderscheit LT. New Orleans asthma. fournal of Allergy 1970;45:257-65.

Ribon A, Glasser $M$, Sudhivoraseth N. Bronchial asthma in children and its occurrence in relation to weather and air pollution. Ann Allergy 1972;30:276-81. Tromp SW. Influence of weather and climate on asthma and bronchitis. Review of Allergy 1968;22:1027-44.

Khot A, Evans N, Lenney W. Seasonal trends in childhood asthma in south east England. Br Med $\mathcal{f} 1983 ; 287: 1257-8$.

- Anderson HR. Increase in hospitalisation for childhood asthma. Arch Dis Child 1978;53:295-300.

- Anderson HR, Bailey P, West S. Trends in the hospital care of acute childhood asthma 1970-8: a regional study. Br Med F 1980;281:1191-4.

"Durbin J. Trend elimination for the purpose of estimating the seasonal and periodic components of time series. In: Rosenblatt $M$, ed. Proceedings of the symposiu 1963.

2 Ashley JSA. Seasonal trends in childhood asthma. Br Med f 1983;287:1721.

13 Bacon CJ. Nebulised salbutamol in the treatment of acute asthma in children Lancet $1978 ; \mathrm{i}: 158$.

Lenney W. Nebulised salbutamol in childhood asthma. Lancet 1978;i:440-1.

is Greenburg L; Field F, Reed JI, Erhardt CL. Asthma and temperature change. Arch Environ Health 1963;8:642-7.

${ }^{16}$ Goldstein I. Weather patterns and asthma epidemics in New York City and New Orleans, USA. Int F Biometeorol 1980;24:329-39.

${ }^{17}$ Horn MEC, Reed SE, Taylor P. Role of viruses and bacteria in acute wheezy bronchitis in childhood: a study of sputum Arch Dis Child 1979;54:587-92.

${ }^{18}$ Gregory PH, Hirst JM. The possible role of basidiospores as air-borne allergens. Nature $1952 ; 170: 414$

${ }^{10}$ Check WA. Common mushroom spores may cause asthma and hay fever in fall. ҰAMA 1982;247:2041.

${ }^{20}$ Spieksma FThM, Spieksma-Boeseman MIA. The mite fauna of house dust with particular reference to the house dust mite Dermatophagoides pteronyssinus. Acarologia 1967;9:226-41.

${ }^{21}$ Van Bronswijk JEMH. Dermatophagoides pteronyssinus (Trouessart 1897) in mattress and floor dust in a temperate climate. $\mathcal{F}$ Med Entomol 1973;10:63-70. ${ }^{22}$ Khot A, Burn R. Seasonal variation and time trends of deaths from asthma in England and Wales 1960-82. Br Med F 1984;289:233-4.

(Accepted 10 May 1984)

\section{MATERIA NON MEDICA}

\section{Columbus, yellow fever, and Louisiana}

An invitation to a research meeting in Puerto Plata, a small but thriving tourist resort on the northern coast of the Dominican Republic, gave me an unexpected chance of visiting the island of Hispaniola, where on Christmas day 1492 Columbus established the first Spanish settlement in the New World. His flagship, the Santa Maria, was wrecked on a sandbank west of Puerto Plata, on part of the coast of what is now Haiti. The ship was near the shore and everyone reached land safely. Since there was only one ship left, the Niña, and she was too small to carry all the Spaniards home, Columbus ordered the crew to collect the timbers and stores from the wreck and to build a fort for 39 sailors, who would be left on the island. The fort was called Navidad (Nativity). Columbus then sailed away on the Niña, hoping to find a prosperous settlement on his return.

When he reached Hispaniola in November 1493 he found Navidad destroyed and all the settlers killed by the Arawak Indians, exasperated by the sailors' cruelty, constant demand for women, and greed of gold. Not far from the first site the ships found a small bay, where Columbus built a second fort called Isabella, but the choice of site was unlucky; within a few months half of the settlers had died of malignant fever and the survivors abandoned the place and went across the island to the south coast, where they built another fort called Santo Domingo.

Through the next 300 years of the turbulent and bloody history of Hispaniola under Spanish rule, and subject to French, British, and Dutch rivalry, tropical disease was a major factor-Cromwell's ill fated attempt to conquer the island was defeated by deadly fevers. But one specific disease had the greatest impact on its future: the outbreak of yellow fever during the revolt of the slaves against their French and
Spanish masters is a classic example in military annals. In 1801 Toussaint L'Ouverture, a remairkable black Haitian leader of the revolt, established his authority over the French occupied western part of the island, built up an army of several thousand irregular but effective troops, all former slaves, and declared himself an independent ruler. Napoleon had plans for alliance with Spain and the rebuilding of the French colonial system in the Americas. To crush the insurgence he sent his brother in law, General Charles Leclerc with an army of veteran troops, including several thousand Polish soldiers, who had fought in French campaigns in Europe.

Leclerc's first successes were impressive, especially when Toussaint was taken prisoner and transported to France, where he died. But the French army could not live off the ravaged land and soon a severe epidemic of yellow fever broke out among the soldiery. Leclerc's pathetic letters to Napoleon were left without answers and no reinforcements came. Leclerc died of yellow fever in November 1802 and his successor surrendered the starved, ragged, fever stricken remnants of the army to the British in Jamaica. Of the 34000 French troops, 24000 died, 8000 were ill in hospitals, and only 2000 were still able to carry arms.

Napoleon decided to wash his hands not only of the San Domingo disaster but also of his plan to maintain French possessions in that part of the Americas. He was then preparing for new wars in Europe, an intended invasion of Britain required massive funds, and it seemed that the best solution was to sell French Louisiana to the Americans. President Jefferson was surprised at the small price of $\$ 15$ million that Napoleon demanded for 1.2 million square miles of a fertile, and well watered land, but in 1803 the deal was concluded. At just over $\$ 10$ per square mile it must have been the world's greatest bargain in real estate. - L I BRUCE-CHWATT, retired university professor, London. 